\title{
Mediating Disputes In The Health Care Field
}

Meyer Drucker, (Email: druckerm@winthrop.edu), Winthrop University Brian Greene, (Email: briansgreenjr@gmail.com), Winthrop University Neal Carter, Winthrop University

\begin{abstract}
This paper will demonstrate how alternative dispute resolution (ADR) should be considered as a method of lessening the negative impact of litigation in the health care field. Probably, an even more important goal is to build and maintain relationships between and amongst parties so that future dealings can be enhanced. The first part of the paper will consider the importance of lowering the rhetoric between disputing parties. A second purpose of this paper is to demonstrate how student written scenarios can be role-played in the classroom so as to energize students in the learning process. Several mock mediations from these student developed cases will be discussed with video clips shown, as they were utilized in the Health and Employment Law 2005 Fall Semester undergraduate courses at Winthrop University. A final purpose is to consider the importance of student input into this learning method.
\end{abstract}

\section{INTRODUCTION TO HEALTH CARE ISSUES}

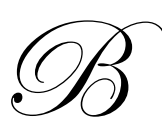

ecause health care costs have consumed more than double the percentage (from about $6 \%$ to over 14\%) of the GNP over the past 40 years, every effort at controlling these costs needs to be examined and promoted. As a side bar, it would be helpful if politicians in Washington and the state capitals would take a more active role in this development, instead of allowing the market place to consume more and more of our hard earned dollars. What is more important to doctor/patient relationships? Is it winning debating points at a trial or obtaining the highest care possible under often emergency circumstances. In this country and the world, we are faced with growing populations that are rapidly aging with a multitude of health issues. Special efforts are needed in providing better relations between providers - such as hospitals, nursing homes and physicians - and patients and employee disputes. Some judgment lapses and malpractice errors by health care providers might be rectified in the future by making examples of their faulty ways of practice and doing business. However, it should be pointed out that juries have too frequently made awards and settlements that are beyond what common sense and justice would dictate.

There is another dimension when providers, such as managed care systems, including HMOs along with insurance companies, attempt to save on medical care charges. When these providers attempt to contain expenses and resources, the patient may be prevented from obtaining the best care, which in turn could lead to more malpractice claims against physicians and nursing homes. It is obvious that a dichotomy develops amongst these competing forces. The market place requires these seemingly bifurcated parties to work together towards more harmonized solutions for the common good.

\section{HANDLING DISPUTES THROUGH LITIGATION}

The traditional method for handling unsolvable disputes between parties in this country has been, and continues to be, formal litigation. It is the standard by which all other methods are to be judged. The overriding advantage, for bringing alleged wrongdoers to court, is that it provides a direct avenue for relief for a plaintiff to satisfy his/her losses. 
Unless other methods prove more desirable, most parties will stick with old-fashioned litigation, and have their day in court. In health care matters, for example, there is a need to establish precedent for certain types of wrongs. It is wrong to continue marketing products that cause overwhelming damage, such as asbestos, especially when the producers had evidence in their files as to the potential harm. Only through litigation against the manufacturers, would there be public disclosure against the wrongdoers, with precedents being made for public protection.

For many other disputable matters, litigation can become disadvantageous, as it can be very expensive in its financial costs in coming to trial. Probably a more important consideration is that relationships are destroyed when a dispute is litigated in public view. Another negative is that members of the jury, being laypersons, could be granting awards on technical matters, totally out of their area of expertise.

\section{ALTERNATIVE DISPUTE RESOLUTION}

Alternative Dispute Resolution (ADR) has been considered as a more positive and efficient way of resolving disputes in the health care field. It is imperative to save relationships between employer and employee, patientphysician, or patient and nursing home. ADR is also highly preferred by court systems in order to trim the judicial system workload through pre-trial settlements. The most used forms of ADR are arbitration and mediation.

\section{Arbitration}

In arbitration, the decision-maker is called an arbitrator, who acts like a judge without a jury. The final decision may be binding or non-binding, depending on the rules of the particular arbitration. The arbitration is private and less formal than a trial; however, it is similar to litigation in that it is often a debate by the parties as who is right and who is wrong. Since the proceedings are less expensive and time consuming than a trial, this makes for an inherent advantage. Some disadvantages are that there is only a decision with no binding precedent for similar future disputes, and there are very limited procedural safeguards since the proceedings are private.

\section{Mediation}

Mediation is an effort to guide fractious parties towards a mutually satisfying resolution of debatable issues facing them in a business or personal matter. The mediator must appear to be unbiased and neutral towards the issues and parties at hand in order to guide them towards a successful ending.

This process is not utopia as some attorneys refuse to seriously participate when they feel their clients can receive or deserve a larger award at a full blown trial. Another built-in disadvantage is that since the parties are appearing on a voluntary basis, they can not be forced to agree to anything.

Since many health and health related disputes contain debatable facts and issues, mediation should and can be utilized as a successful tool. With the parties in open discussion, they can improve their relationships since the proceedings are very flexible. The vast majority of mediations have ended in settlements without the high costs of litigation. When utilized properly, the advantages to using mediation become apparent when the parties negotiate side by side with the assistance of the trained, third party neutral.

\section{STUDENT ROLE-PLAYING IN THE HEALTH CARE FIELD}

(See Appendix A for a summation of Pros and Cons of Mediation)

The use of classroom mediation applications should be very beneficial for any employment law or health care law course. In Fall 2005, the instructor taught both of these courses at Winthrop University; he decided to test this theory by challenging students to write scenarios involving health and employment related issues. The intent was to glean factual material from a student's own experiences, and see how a result could be played out in the classroom. Effective mediation could result in fairer settlements on issues pertaining to real situations in the health care industry. 
Four (4) different video tape clips will be utilized to show various concerns about student educational development in the process.

\section{Case A: Amputated Arm—Lacking Standard Of Care}

\section{Case Facts}

Patient Williams had a badly infected and broken hand, initially refused an amputation recommended by the surgeon. Williams wanted to take drug treatment before consenting to the amputation. The physician, Dr. Boston, a well-known orthopedic surgeon, was also President of a private orthopedic surgical hospital in Charlotte, N. C. Dr. Boston was out of the city on a two-week medical training course as the patient's problems worsened. Eventually Ms. Williams had her entire arm amputated - she received a significant settlement because of the physician's negligence in his follow-up treatment.

\section{Video Clip \#1}

This mediation clip shows how excellent camera work can capture unrehearsed performances by student role playing. This mediation took place during the last stages of the course. It shows how the patient and the physician saw things so differently as to what they should be doing. The physician thought she was doing all she could under the restrictions the patient put her under, while the patient's expectations were that the physician should be more flexible in treating her. This case shows that medical personnel should consider needs of patients when the patients do not immediately follow their medical advice, in order to avoid future malpractice issues.

\section{Case B: Religious Discrimination By Hospital}

\section{Case Facts}

An African-American male nurse, Tony, went to the EEOC when the Tuddist Hospital would not hire him even though he was more qualified academically than some of the hired white female nurses; the African-American nurse also had four (4) years of experience as an orderly while attending the nursing program at USC, where he graduated in the top $20 \%$ of his class. He received excellent appraisals while he was in attendance. One of the requirements for being a staff nurse at the Hospital was to be: 'a Tuddist, in training to be one, or in a religion not in conflict with Tuddism.' The African-American was a holy-roller; the Hospital took the position this was a conflict. The EEOC wanted to establish a precedent in Federal Court on this matter, but the Judge ordered an arbitration of the matter, since mediation efforts had failed.

The Arbitrator took the position the Hospital did not have to hire him since it was important to the operation of the hospital that their healing practices required its personnel not to be in conflict with the tenants of their medical practices. The Arbitrator attempted to get a recommendation for employment in other hospitals as the aggrieved party had been an outstanding part-time employee from the Director of Human Resources at the Tuddist Hospital. Millie Toomuch agreed, but the African-American refused this suggestion, and that is where the arbitration ended. The conclusion by the arbitrator was that a purely religious institution can discriminate in its hiring practices.

\section{Video Clip \#2}

The arbitration clip shows the last exchange between the Human Resources Director and the aggrieved black male nurse. Millie said part of the healing process in the Tuddist Hospital was that you could not eat meat and fowl products. For patients to see Tony, a nurse, eating Southern fried chicken would send confusing signals to patients. It should be noted that the Millie was a Tuddist African-American herself. The Arbitrator agreed with the nurse that the hospital was discriminating against him, but the employer had a legitimate Bona Fide Occupational Requirement in doing so. 
This video clip also shows the Arbitrator asking leading questions. This is fine as long as the purpose is to establish the facts in the case so that a reasonable decision can be made. This approach would not be satisfactory if it appeared to one of the parties that the other party was getting more favorable treatment in the process.

\section{Case C: Unmarried Pregnant Teenager-Medical Malpractice}

\section{Case Facts}

A sixteen-year old unmarried teenager, Allison, received good reports from her OBGYN Physician, Dr. Strong, on all of her prescribed visits while she was in prenatal care. However, during her $7^{\text {th }}$ month of pregnancy, Allison had rapid weight gain with swelling in her arms and legs. Dr. Strong did not express concern about this development even though her weight had gone from 140 to 280 and her blood pressure was 280/160; all he said was that "she was retaining fluid, no big deal." Dr. Strong noted Allison was on target in his conversations with her, in spite of the weight gain and extremely high blood pressure noted in the records. When she began showing signs of labor, Dr. Strong was on vacation. Allison's Mother called Dr. Strong's office; she was referred to Dr. Thomas, who was handling Dr. Strong's emergency situations. Upon examination, Dr. Thomas could not believe that Allison's vital signs, documented in the records, indicated she seemed to have toxemia, which is a treatable blood disease. Dr. Thomas proceeded to deliver Allison's son, but had to pump magnesium into her blood to regulate her blood pressure, with extra monitoring and hourly blood samples because of the toxemia condition. After this very difficult delivery, which placed both her life and her child in jeopardy, she sued Dr. Strong.

\section{Video Clip \#3}

Dr. Strong tries to avoid liability by indicating that both Allison and child are now in very good health so why should he be liable as he could not prevent Allison from overeating super-sized hamburgers, french fries and regular cokes from McDonalds as standard fare twice a day. When the parties seem to go 'around in circles,' the mediator suggests that a caucus be called; this is when the mediator interviews each of the participants with a one-onone discussion. Without taking sides, the mediator asks Dr. Strong whether he is going to just let this mediation slide by without a settlement. The mediator expresses her concern to Dr. Strong if he allows this case to go to court that Allison is a formidable witness, and he may be exposing himself to a sympathetic jury with a large award if he doesn't attempt to settle this matter through mediation. The mediator had been appointed in hopes of settling this matter through mediation.

\section{Role Reversal}

It should be noted that 'Allison' (not her real name), who wrote this case for class presentation, is in real life an honors Management student at Winthrop University. She received a significant private settlement and is utilizing these funds to further her education. 'Allison' lost most of that excess weight; both she and her child have recovered from their illnesses from the child birth.

'Allison' also played a convincing 'Dr. Strong' role in the classroom. This type of role playing is called "Role Reversal." The purpose of this activity is to anticipate potential defensive tactics and how to overcome those in a real trial or a mediation or arbitration.

\section{Case D: Foreign Language Plaintiff (Spanish)}

\section{Case Facts}

The plaintiff, a Spanish speaking American citizen, spoke very little English and had trouble digesting the instructions on her medicine bottle. She was suing the pharmacist because her understanding was that she was to take 11 tablets per day, when in English it clearly indicated she was to take 1 tablet per day. 


\section{Video Clip \#4}

This was definitely one of the lighter moments in the class as the plaintiff attempted to fake her Spanish and played the role as if she was also somewhat retarded, which she is not. There is a very valid purpose in that the United States is becoming more and more non-English speaking. Americans, including business personnel and other professionals, need to be more considerate of their clientele, and to become more consumer-friendly and accommodating towards those who speak another language.

\section{CRITICAL STUDENT COMMENTS}

(See Appendix B for summation of student comments)

When the instructor introduces learning theories that are different than those familiar to students, s/he should be willing to listen to student comments and concerns. A part of the course requirements included critical student comments on techniques and process. These were selected as the most germane:

(a) The most successful mediations came about when the mediator was able to set the tone for the discussion and laid some ground rules to be followed. Everyone should engage in good faith bargaining for an opportunity to obtain an equitable outcome.

(b) Mediator should remain neutral; however, this neutrality can still be maintained by making suggestions to the parties, while not forcing a settlement on either party.

(c) The mediator often needed private caucuses with each of the parties as to what outcome would be ideal for them, and where there would be room for negotiation. The mediator should not disclose what each party discloses at these caucuses. Therefore, it is important that the mediator provide the atmosphere for the parties themselves to negotiate an endurable settlement.

(d) Since most of the mock mediations were written by students instead of being provided from a text or from the instructor, this gave the impression that students had a stake in the process. Several of the authors of their scenario were asked to play opposite roles when they/friends/family had actually been parties to a dispute. On first impression this may appear to be confusion, however, in reality it gave the role author a chance to build one's own case and learn defensive tactics.

(e) It is more important to learn the proper technique from the mediations than obtaining a particular settlement amount. This may include the introduction of appropriate evidence, and/or the inclusion of outsiders, such as experts or translators.

For example, the plaintiff, an unmarried pregnant teenager, (Case $\mathrm{C}$ above) was asked to play as a role-reversal against the physician that she was suing. In this role-play, the 'physician' produced records, which contradicted what the plaintiff was claiming. Therefore, appropriate evidence or expert witnesses should be utilized to boost one's case. Medical records are extremely important in many cases in proving whether a plaintiff or defendant is or is not telling the truth.

(ii) In the Spanish case (Case D) it was more important that students recognized there was a need for a translator to be at the mediation than who won the mediation. In other words, students can learn more from technique usage than how much award one receives from the mock mediation.

\section{POSTSCRIPT}

A practicing attorney, Neal Lourie of Columbia, S. C. specializing in healthcare malpractice issues was consulted on December 26, 2005, about the usage of mediation in undergraduate education. He was somewhat surprised at this attempt as mediation/negotiation learning methodology is relatively new in law school programs. In viewing the video tapes used in this presentation, he made the following observation:

(a) "It is a good idea to supplement group learning activities with negotiation/mediation methodology. The skills obtained in this fashion would be important for any major, but especially so for business and pre-law students. 
(b) If they don't utilize these valuable techniques in a business or legal setting, at least they should be able to improve their negotiating skills in their personal lives when they purchase large items, such as homes and vehicles."

\section{AFTERTHOUGHT}

The original purpose of this article/presentation was to summarize why mediation should be utilized in resolving disputes in the health care field, as well as it becoming an important learning tool in the undergraduate classroom through the use of role-playing. After reviewing student input, the authors for this article, feel that learning and utilizing proper techniques are paramount to its successful usage.

\section{REFERENCES}

1. Caldon, David. Medical Malpractice Disputes in the Age of Managed Care, www.mediate.com/articles/caldon.cfm.

2. Drucker, Stabenaw and Cooley. Using Mediation to Defuse Potential Title VII Situations, Journal of Business \& Economics Research, June 2005, pp. 51-56.

3. Fisher, Robert, and Ury, William. Getting to Yes, $2^{\text {nd }}$ Ed. New York: Penguin Group, 1991.

\section{APPENDIX A}

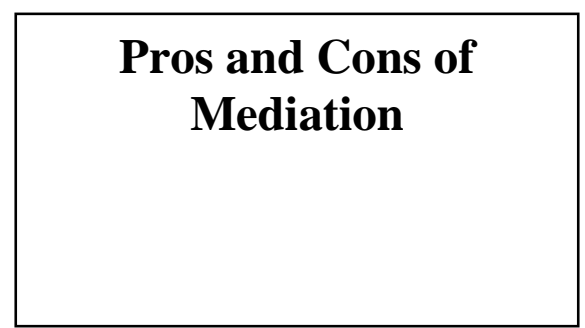

\begin{tabular}{|ll|}
\hline \multicolumn{2}{|c|}{ LITIGATION } \\
ADVANTAGES & DISADVANTAGES \\
-Need to be heard & - Expensive \\
-Sets precedent for & - Destroys \\
patient care & relationships \\
-Public disclosure & - Technical issues \\
for wrongdoers & resolved by \\
& laypersons \\
& \\
\hline
\end{tabular}

\section{MEDIATION}

\section{ADVANTAGES}

-Maintains most of the advantages of litigation/arbitration

-Attempts to improve relationships of all the parties

-Very flexible and cuts costs

-Vast majority of mediations result in settlements

\section{WINTHROP UNIVERSITY}

Professor Meyer Drucker, JD,LLM,CPA

Brian S. Greene Jr., B.S.

Neal Carter, B.S.

\begin{tabular}{|ll|}
\hline \multicolumn{2}{|c|}{ ARBITRATION } \\
ADVANTAGES & DISADVANTAGES \\
-Less expensive & -No binding \\
than litigation & precedent for \\
-Allows for qualified & similar disputes \\
factfinders & -Lacks \\
& procedural \\
& safeguards \\
& \\
\hline
\end{tabular}

\section{MEDIATION}

DISADVANTAGES

-Can not force parties to agree to anything.

-Can be time consuming without results

-Participation is voluntary

-Some attorneys refuse to mediate. 


\begin{tabular}{|c|}
\hline STUDENT COMMENTS \\
AND CRITIQUES \\
Winthrop University \\
Professor Meyer Drucker, JD, LLM, \\
CPA \\
Brian S. Greene Jr., B.S. \\
Neal Carter, B.S. \\
\hline
\end{tabular}

\begin{tabular}{|c|}
\hline IMPORTANCE OF \\
NEUTRAL MEDIATOR \\
-Suggestions are paramount at times \\
-Not forcing a settlement \\
\end{tabular}

\section{MOST MOCK MEDIATIONS WRITTEN BY STUDENTS}

-Stake in Process

-Role Reversal-Defensive Tactics

\section{MOST SUCCESFUL MEDIATIONS}

-Mediator was able to set the tone

-Mediator set ground rules

-Good faith Bargaining

\section{PRIVATE CAUCUSES WITH} EACH PARTY

-Realistic but ideal or bottom-line, settlement ideas from each party

-Negotiate between serious parties

\section{PROPER TECHNIQUE}

-More important than settlement amount

-Appropriate Evidence

-Need for experts/translators 


\section{NOTES}

